\title{
Key Indicators Influencing Team Effectiveness in Project-Based Team
}

\section{Fauzia Seftyandra and Arviansyah}

Master of Management, Faculty of Economics and Business, University of Indonesia, Salemba, Indonesia

\begin{abstract}
Teamwork is essential for any organizations to undertake particular purposes. Team members work together as a group combining their knowledge and skill to attain higher productivity and performance. An effective team is considered desired to achieve optimal performance. However, there are only a few studies of effectiveness in teams which are operated based on projects. This paper identifies and classifies the critical indicators of effectiveness in project-based teams to garner invaluable insights into how they influence team outcomes. We conduct a systematic literature review to categorize a set of indicators that affect team effectiveness based on human resource and project management literature. We follow the review method and reveal eighteen indicators of effectiveness from thirty-five publications as the basis for transforming project-based teams into effective teams. The result provides deeper insights into the importance of exercising and improving teamwork. Additionally, this paper recognizes a complex system of interdependence among indicators and identifies potential issues in adopting a strategy for the project-based team in organizations. The paper contributes to the current knowledge by providing the necessary groundwork for further research and development in this area.
\end{abstract}

Corresponding Author:

Fauzia Seftyandra

seftyandra@gmail.com

Received: 30 December 2019

Accepted: 29 January 2020

Published: 6 February 2020

Publishing services provided by Knowledge E

(c) Fauzia Seftyandra and Arviansyah. This article is distributed under the terms of the Creative Commons

Attribution License, which permits unrestricted use and redistribution provided that the original author and source are credited.

Selection and Peer-review under the responsibility of the 6 th ICOEN 2019 Conference Committee.

Keywords: effectiveness, teamwork, project-based, teams, key indicators

\section{Introduction}

Teams from different types of organizations must be able to coordinate and cooperate to fully utilize their knowledge and experience to ensure that timely information can be shared and transferred effectively throughout the project life cycle [1]. Project teams are commonly used in organizations and have been widely studied [2]. The objective of this study is to identify and classify the critical indicators of effectiveness in project-based teams acquiring insights into how they influence team outcomes. Moreover, researchers in the area of organization and management have started to utilize Systematic Literature Review (SLR) into their research design [3] to acquire novel insights within the area; we 
conduct an SLR to delve into recent high-quality publications to achieve the objective. This study thus provides overview of contemporary theoritical in this sector [4].

\section{Methods and Equipment}

\subsection{Methods}

\subsubsection{Study Literature Review (SLR)}

In this study, we opt to carry out SLR focusing on the leading academic journal that publish research in project management and human resource management. Performing a systematic literature review comprises ten actions within three phases: planning, conducting, and reporting the review [5]. We use nine academic journals as references for this review. We search for full-text articles published from 2012 to 2018 using the terms "project" and "team effectiveness" within our targeted journals via Google Scholar; the search generates a total of 176 publications. Table 1 shows the initial search of the combined journals from both project and human resources management. The identified publications are then examined based on their titles and abstracts and analyzed based on their content. Figure 1 shows the process utilized to obtain the data for the systematic literature review in this study.

TABLE 1: Keywords, time frame, and targeted journals.

\begin{tabular}{|l|c|c|c|}
\hline Keywords & Time Frame & Journal & Result \\
\hline $\begin{array}{l}\text { "team effectiveness" } \\
\text { "project" }\end{array}$ & $\mathbf{2 0 1 2 - 2 0 1 8}$ & International Journal of Project Management & 46 \\
\hline & Project Management Journal & 13 \\
\hline & International Journal of Managing Projects in \\
& Business & 14 \\
\hline & Construction Management and Economics & 8 \\
\hline & Journal of Cleaner Production & 4 \\
\hline & Human Resource Management Review & 32 \\
\hline & Organization Science & 30 \\
\hline Total & Management Science & 20 \\
\hline
\end{tabular}

The 35 articles have gone to further detailed review. We synthesize the identified indicators and consolidate them based on the similarity of their definitions. The identified 


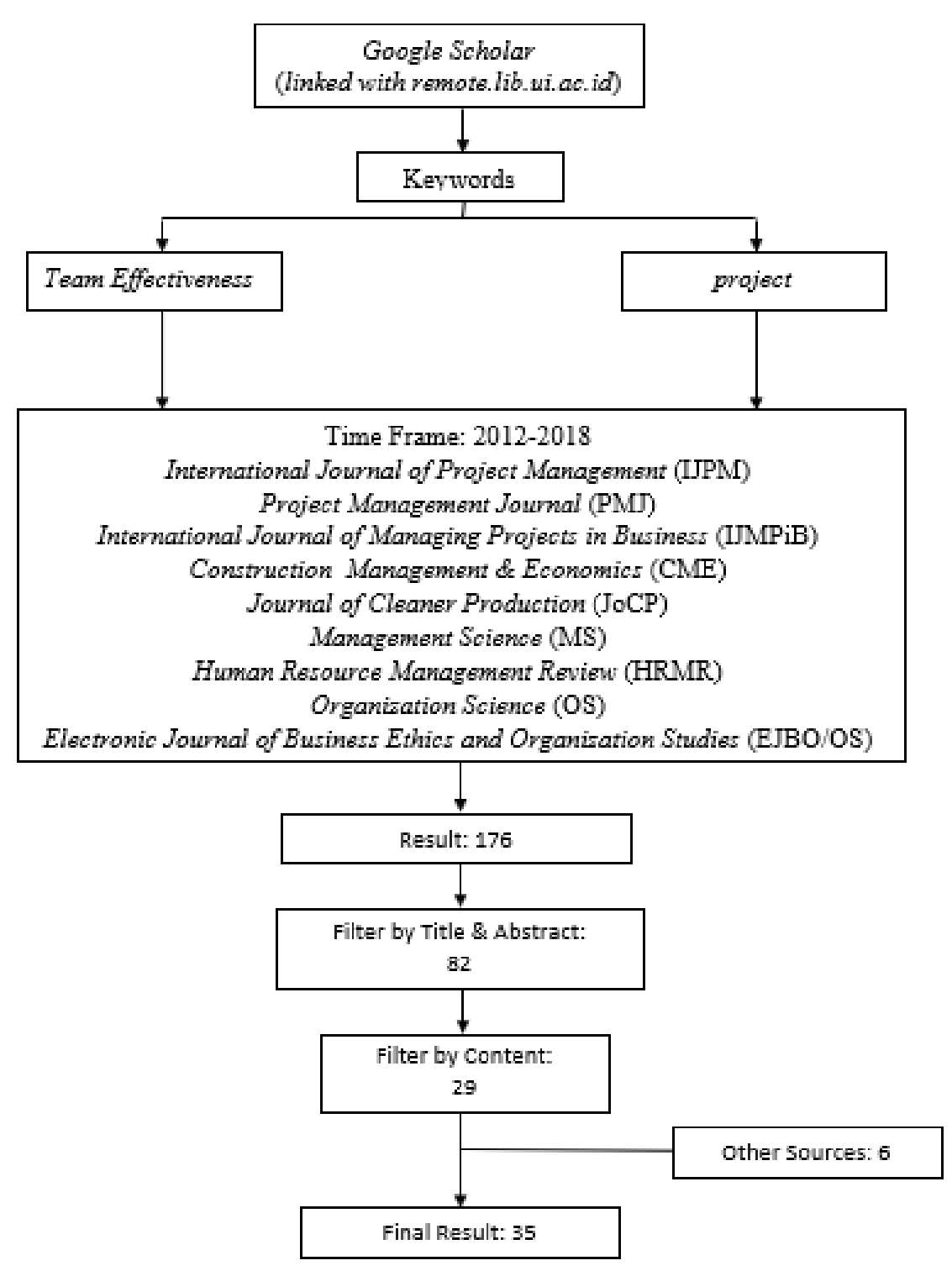

Figure 1: Systematic literature review process.

indicators are associated with project-based teams and considered as the determinant of project success.

\section{Results}

Our analysis uncovers eighteen critical indicators that can be used to assess team effectiveness as shown in Table 2. 
TABLE 2: Key indicators influencing team effectiveness.

\begin{tabular}{|c|c|c|}
\hline Key Indicators & Definition & References \\
\hline Team Composition and Staffing & $\begin{array}{l}\text { The optimal combination of all } \\
\text { team members with the right } \\
\text { composition }\end{array}$ & $\begin{array}{l}\text { [7], [8], [9], [10], [2], [11], [12], [13], } \\
\text { [14], [15] }\end{array}$ \\
\hline $\begin{array}{l}\text { Information \& Communication } \\
\text { Technology Systems }\end{array}$ & $\begin{array}{l}\text { Use of the latest technology as } \\
\text { a system for team needs in } \\
\text { daily work }\end{array}$ & [8], [9], [16], [17], [11], [16], [17] \\
\hline Leadership & $\begin{array}{l}\text { The ability of leaders to } \\
\text { influence their members to } \\
\text { achieve goals }\end{array}$ & $\begin{array}{l}\text { [18], [8], [19], [20], [10], [21], [2], } \\
{[14],[22],[23],[24]}\end{array}$ \\
\hline Management Support & $\begin{array}{l}\text { Full support and commitment } \\
\text { from top management to help } \\
\text { the team }\end{array}$ & [18], [25], [2], [11], [26], [13] \\
\hline $\begin{array}{l}\text { Creativity, Innovation, and } \\
\text { Improvement }\end{array}$ & $\begin{array}{l}\text { Encourage innovative thinking } \\
\text { that can contribute to improving } \\
\text { contribution for teams }\end{array}$ & [27], [11], [26], [28], [29], [15], [23] \\
\hline Trust and Respect & $\begin{array}{l}\text { All members need to trust each } \\
\text { other and be treated equally }\end{array}$ & [16], [11], [26], [28], [29] \\
\hline Encouraging Initiative & $\begin{array}{l}\text { Motivate all team members to } \\
\text { come up with a good and } \\
\text { doable idea that can make a } \\
\text { positive contribution to the team }\end{array}$ & [8], [19], [11], [26], [29], [22], [30] \\
\hline Teamwork & $\begin{array}{l}\text { Responsive to changes and } \\
\text { uncertainties well during the } \\
\text { project }\end{array}$ & $\begin{array}{l}\text { [16], [11], [26], [12], [13], [14], [29], } \\
\text { [10] }\end{array}$ \\
\hline Security & $\begin{array}{l}\text { Ensure the health and safety of } \\
\text { members working there } \\
\text { (Physiological and } \\
\text { psychological safety) }\end{array}$ & [16], [18], [19], [11], [30] \\
\hline Information Sharing & $\begin{array}{l}\text { Information should be } \\
\text { accessible and available to all } \\
\text { team members }\end{array}$ & $\begin{array}{l}\text { [7], [11], [26], [12], [31], [29], [22], } \\
\text { [23] }\end{array}$ \\
\hline Close Monitoring & $\begin{array}{l}\text { Ability to record all existing } \\
\text { activities, compare with targets } \\
\text { and analyze errors and take } \\
\text { corrective action }\end{array}$ & [32], [19], [26], [15], [29] \\
\hline Common Goals & $\begin{array}{l}\text { All members work together and } \\
\text { focus on achieving the goals of } \\
\text { the project }\end{array}$ & [2], [11], [26], [29] \\
\hline Clear Standard and Roles & $\begin{array}{l}\text { There are clear standards for } \\
\text { doing things and their } \\
\text { respective roles are well } \\
\text { defined in project activities }\end{array}$ & [7], [19], [26], [13], [14] \\
\hline $\begin{array}{l}\text { Decision Making and Problem } \\
\text { Solving }\end{array}$ & $\begin{array}{l}\text { Empower members with greater } \\
\text { responsibilities and more } \\
\text { access to resources }\end{array}$ & [16], [11], [12], [14], [29] \\
\hline Reward Systems & $\begin{array}{l}\text { Compensation, promotion, or } \\
\text { bonus is given by the } \\
\text { organization in return for good } \\
\text { performance. }\end{array}$ & {$[8],[2],[12],[10],[30]$} \\
\hline
\end{tabular}




\begin{tabular}{lll} 
Key Indicators & Definition & References \\
Training & $\begin{array}{l}\text { A formal program provided by [8], [10] } \\
\text { the organization to develop } \\
\text { knowledge, skills, or attitude }\end{array}$ \\
\hline $\begin{array}{l}\text { No Organizational Defined } \\
\text { Boundaries }\end{array}$ & $\begin{array}{l}\text { Working without an } \\
\text { organization's identity will } \\
\text { ensure everyone realizes they [9] [29] } \\
\text { are part of the team }\end{array}$ \\
\hline "No Blame" Culture & $\begin{array}{l}\text { Problem-solving with collective [16], [11], [29] } \\
\text { identification and acceptance of } \\
\text { collective responsibility }\end{array}$
\end{tabular}

\section{Discussion}

Organizations typically employ project teams to deal with the increasing global competition in the marketplace and the current rapid change in information technology. A project-based team is a temporary entity that executes specific time-constrained tasks and then disbands [6]. The result of the systematic literature review shows that eighteen key indicators are influencing team effectiveness. It is suggested to consider the indicators independently since each one represents a critical element of team effectiveness despite the possibility of interdependence among indicators [1].

\section{Conclusion}

The consolidated set of key indicators in this review is the first step in the development of team effectiveness in project-based teams. The subsequent step is to validate this set against the views of experienced practitioners.

Furthermore, the question arises whether eighteen indicators are all required in fostering effectivity in a project-based team, or whether a subset of this dominate. Having determined which key indicators to proceed with, further research is required to determine the variables which influence each indicator and suitable measures, preferably objective measures, for their assessment. Researchers can then use a combination of research methods in the form of qualitative methods as well as quantitative methods for each indicator that can help the team development more effectively. Further research may add other potential indicators by extending the time range of the study in order to capture more literature. 


\section{Acknowledgement}

The authors would like to thank their colleague for their contribution and support to the research. They are also thankful to all the reviewers who gave their valuable inputs to the manuscript and helped in completing the paper.

\section{Conflict of Interest}

The authors have no conflict of interest to declare.

\section{References}

[1] Izam Ibrahim, K., Costello, S. B., \& Wilkinson, S. (2013). Key practice indicators of team integration in construction projects: a review. Team Performance Management: An International Journal, vol. 19, pp. 132--152.

[2] Liu, W. H., \& Cross, J. A. (2016). A comprehensive model of project team technical performance. International Journal of Project Management, vol. 34, pp. 1150--1166.

[3] Aarseth, W., Ahola, T., Aaltonen, K., Økland, A., \& Andersen, B. (2017). Project sustainability strategies: A systematic literature review. International Journal of Project Management, vol. 35, pp. 1071--1083.

[4] Arviansyah, A., Berghout, E., \& Tan, C. (2011). Evaluation of ICT Investment in Healthcare: Insights and Agenda for Future Research, in Proceedings of the 5th European Conference on Information Management and Evaluation (ECIME).

[5] Brereton, P., Kitchenham, B. A., Budgen, D., Turner, M., \& Khalil, M. (2007). Lessons from applying the systematic literature review process within the software engineering domain. Journal of Systems and Software, vol. 80, pp. 571--583.

[6] Kozlowski, S. W. J., \& Bell, B. S. (2003). Work Groups and Teams in Organizations. New York, Cornell University ILR School: Wiley-Blackwell

[7] Bell, S. T., Brown, S. G., \& Weiss, J. A. (2017). A conceptual framework for leveraging team composition decisions to build human capital. Human Resource Management Review, pp. 1--14.

[8] Dulebohn, J. H., \& Hoch, J. E. (2017). Virtual teams in organizations. Human Resource Management Review, vol. 27, pp. 569--574.

[9] Hietajärvi, A., Aaltonen, K., \& Haapasalo, H. (2017). Managing integration in infrastructure alliance projects Dynamics of integration mechanisms. Journal of Managing Project in Business, vol. 10 no. 1, pp. 5--31. 
[10] Hoch, J. E., \& Dulebohn, J. H. (2017). Team personality composition, emergent leadership and shared leadership in virtual teams: A theoretical framework. Human Resource Management Review: vol. 27, pp. 678--693.

[11] Che Ibrahim, C. K. I., Costello, S. B., \& Wilkinson, S. (2015). Key indicators influencing the management of team integration in construction projects. International Journal of Managing Projects in Business, vol. 8 no. 2, pp. 300--323.

[12] Jiang, J. Y., \& Liu, C. (2015). High performance work systems and organizational effectiveness: The mediating role of social capital. Human Resources Management Review, vol. 25, pp. 126--137.

[13] Suprapto, M., Bakker, H. L. M., \& Mooi, H. G. (2015). Relational factors in owner - contractor collaboration: The mediating role of teamworking. Journal of Project Management, vol. 33 no. 6, pp. 1347--1363.

[14] Suprapto, M., Bakker, H. L. M., Mooi, H. G., \& Moree, W. (2015). Sorting out the essence of owner -- contractor collaboration in capital project delivery. Journal of Project Management, vol. 33 no. 3, pp. 664--683.

[15] Creasy, T., \& Anantatmula, V.S. (2013). From every direction - how personality traits and dimensions of project managers can conceptually affect project success. Project Management Journal, vol. 44, no. 6, pp. 36-51.

[16] O'Neill, T. A., \& Salas, E. (2017). Creating high performance teamwork in organizations. Human Resources Management Review, pp. 1--7.

[17] Lindeblad, P. A., Voytenko, Y., Mont, O., \& Arnfalk, P. (2015). Organisational effects of virtual meetings. Journal of Cleaner Production, pp. 1-11.

[18] Ajmal, M., Malik, M., \& Saber, H. (2017). Factor analyzing project management practices in the United Arab Emirates. Journal of Managing Projects in Business, vol. 10, issue 4, pp. 749-769.

[19] Valentine, M. A., \& Edmondson, A. C. (2015). Team Scaffolds: How Mesolevel Structures Enable Role-Based Coordination in Temporary Groups. Organization Science, vol. 26 no. 2, pp. 405--422.

[20] Hassan, M. M., \& Bashir, S. (2017). The Impact of Project Managers Personality on Project Success in NGOs: The Mediating Role of Transformational Leadership. Project Management Journal, vol. 48, no. 2, pp. 74-87.

[21] Aga, D. N., \& Noorderhaven, N. (2016). Transformational leadership and project success: The mediating role of team-building. Journal of Project Management, vol 34, pp. 806-818.

[22] Aronson, Z. H., Shenhar, A., \& Patanakul, P. (2013). Managing the Intangible Aspects of a Project: The Affect of Vision, Artifacts, and Leader Values on Project Spirit and 
Success in Technology Driven. Journal of Project Management, vol. 44, no. 1, pp. 35-58.

[23] Hoch, J. E., \& Dulebohn, J. H. (2013). Shared leadership in enterprise resource planning and human resource management system implementation. Human Resource Management Review, vol. 23 no. 1, pp. 114--125.

[24] Varella, P., Javidan, M., \& Waldman, D. (2012). A Model of Instrumental Networks: The Roles of Socialized Charismatic Leadership and Group Behavior. Organization Science, vol. 23, no. 2, pp. 582-595.

[25] Albert, M., Balve, P., \& Spang, K. (2017). Evaluation of project success: a structured literature review. Journal of Managing Projects in Business, vol 10, no. 4, pp 768-821.

[26] Hakanen, M., Häkkinen, M., \& Soudunsaari, A. (2015). Trust in building highperforming teams: conceptual approach. Journal of Business Ethics and Organization Studies, vol. 20, no. 2, pp. 43--53.

[27] Bell, S. T., Brown, S. G., \& Weiss, J. A. (2017). A conceptual framework for leveraging team composition decisions to build human capital. Human Resource Management Review.

[28] De Jong, B. A., Bijlsma-frankema, K. M., \& Cardinal, L. B. (2014). Stronger Than the Sum of Its Parts? The Performance Implications of Peer Control Combinations in Teams. Organization Science, pp. 1-19.

[29] Aapaoja, A., Herrala, M., Pekuri, A., \& Haapasalo, H. (2013). The characteristics of and cornerstones for creating integrated teams. Journal of Managing Projects in Business, vol. 6, no. 4, pp. 1753-8378.

[30] Jetu, F. T. (2013). Cultural values influencing project team success An empirical investigation in Ethiopia. Journal of Managing Projects in Business, vol. 6 no. 3, pp. 425--456

[31] Guenter, H., Emmerik, I. J. H. Van, \& Schreurs, B. (2014). The negative effects of delays in information exchange: Looking at workplace relationships from an affective events perspective. Human Resource Management Review, vol. 24 no. 4, pp. 283--298.

[32] Albert, M., Balve, P., \& Spang, K. (2017). Evaluation of project success: a structured literature review. Journal of Managing Projects in Business. 